\title{
Enhancing the Students' Positive Attitude in Learning Business English by Using Technology
}

\author{
Lia Agustina*
}

State Polytechnic of Malang, Indonesia

CorrespondingAuthor: Lia Agustina,E-mail: lia_alfan2d@yahoo.com

\section{ARTICLE INFO}

\section{Article history}

Received: August 28, 2017

Accepted: October 20, 2017

Published: December 30, 2017

Volume: 8 Issue: 6

Advance access: December 2017

Conflicts of interest: None

Funding: None

Key words:

Enhance,

Students 'Attitude,

Technology

\begin{abstract}
Many research findings have stated that the use of technology in EFL classroom results invaluable achievements and develops positive attitudes. Technology may integrate sounds, pictures, motions, and colors that fi ure out a natural picture of real life. The aim of the study was to enhance the students' attitude toward learning English by using technology of internet that used as the data-finding resources while computer software used as an instrument to do the assigned project. The instruction was performed in a project simulating business meeting, done in a group of seven members. The study was an action research using a total of 52 students from Accounting Department of State Polytechnic of Malang in the year of 2015/2016. The study took 12 meetings, with 90 minutes for each meeting. The data were collected through interviews, questionnaire, and direct observation, pre-test and post-test. Result of the study showed that by using technology, the students' positive attitude toward learning English was promoted.
\end{abstract}

\section{INTRODUCTION}

\section{Background of the Study}

Learning a second and a foreign language always requires a serious effort. Fatigue and boredom can come easily to every student. Technology can be used as a media to give an impact on students' attitude positively. The most effective technology tool in the process of learning is a computer and internet. Internet has vast realistic and authentic resources. Internet produces an up-to-date knowledge. It is a cheap tool to be used as a source of data. Based on that reason, the teacher-researcher intended to enhance the students' attitude in learning English by using technology.

The use of computer and internet brings beneficial to the students. It increases students' motivation, creativity, knowledge, tolerance and responsibility in learning English as students see a real world in the classrooms. Internet provides films and music that influence on students' way of thinking that creates enjoyable atmosphere in such a way and also stimulate students' critical thinking.

Wang (2004) stated that When, in the classroom, learners of language have the factors of communication, which are real and desirable, they tend to gain progress in their skills of the language learned. Technological apparatus of many kinds are potential to make them feel freer and more encouraged. They help them to be more active, more excited, and more involved in the process of learning.
Jonassen (2000) discusses that technology in EFL classroom encourages not only the students but also the teacher in a positive way. Brown (2003) explains that Internet increases the quality of language learning and provides available education.

\section{Problem Statement}

Based on the preliminary study, there was a strong indication that the students of the Accountancy Department- State Polytechnic of Malang are less motivated in learning English. Some students feel that they have limited knowledge and lack of confidence to practice what they have learned this is ironic as Polytechnics is designed to put more emphasis on practice than on theory. This low positive attitude is, by all means, a serious weakness that needs to be seriously looked into and worked out.

As stated previously, a lot of research findings stated that integrating technology in classroom instruction can promote the students positive attitude toward learning. Therefore, it makes sense that the problem of students' low positive attitude at State Polytechnic of Malang toward English learning might be addressed by exploring the integration of technology into English instruction in the institution. In this global era, successful English instruction is important for the institution to survive and to be competitive. 


\section{Research Objective}

In general, the aim of the study was to enhance the students' positive attitude, creativities, critical thinking, tolerance, motivation, and responsibility in learning Business English in EFL classroom by using technology.

\section{Research Question}

How can the students' positive attitude toward learning Business English be enhanced by making the most use of the potential of technology?

\section{The Significance of the Study}

The study is significant as it has a power to maximize input in Business English learning. It is helpful for the teachers' efforts to make students motivated, creative, think critically, tolerant, and responsible in their learning. The use of technology as a media for processing the Business learning in the EFL classroom provides students with opportunities to develop skills; not only soft skills but also the skills on reading, speaking, writing, or listening. So this implementation is quite important to help students to prepare their future.

\section{The Scope and Limitation of the Study}

The model was implemented to the students who were at the third semester of the Accountancy Department-State polytechnic of Malang in the year of 2015/2016.

The Action Research was conducted to improve the student' creativities, students critical thinking, students' motivation, students' responsibility and students' tolerance along the process of learning Business English by using technology. The implementation of the model took 12 meetings.

The materials used were taken from the internet that was used as a source of reading materials, summarizing/synthesizing the materials as a practice of reading skill and writing skill and then it should be performed by using power point that was used as a media to practice the speaking and listening skills.

\section{LITERATURE REVIEW}

The use of technology, a computer and internet in language instruction bring an atmosphere closer and warmer between teacher and students event among the students themselves. It increases not only on students' skills and knowledge but also stimulates students' attitude to be creative, to be tolerant and to be more responsible on their learning. Mostly students like using Internet for it are beneficial, enjoyable. Blake (2008) stated that computer technology bring a very important role in enhancing EFL learners. Gordon (2007, p.179) stated that the use of technology can help present a number of benefits in the more general learning process and it is important to align this with the concept of language learning in general to highlight how technology has had a major impact.

While Chartrand (2004, p 15) stated that using technology in EFL teaching can encourage students to be more re- sponsible for their EFL learning, increase their confidence, and motivate them by providing with interesting materials.

Learning English using a computer and internet brings an important role during the journey of learning. Roberts, 2005, p. 2-3, stated that technology promotes higher achievement and positive attitude toward the subject matter. A Computer and internet have a benefici 1 function to promote problem-solving skills said Chin, 2004, p. 111 that would sharp the students' critical thinking, and O'Leary, 2005, p. 2 said that technology could be used as a tool to facilitate collaborative discussions and activities, and Schulte, 2010, p. 7, add more function on the use of technology (a computer and internet) that it provides more opportunities for students to interact among their classmate.

It is clear; a computer and internet have a huge resource. It provides realistic, authentic native-speaker models of the language (audio and text). Teachers and students can easily looking for information and all materials needed in a faster and cheaper way. The Internet also updates knowledge, materials and information every second. The source of reading materials from the Internet could be used for practice of reading and writing skills that could be followed with exercises; those were used to practice the speaking and listening skills

There was a research done by Hamad Youssef Al-Maini (Saudi, 2011) practicing an internet used as a way of communication. His students made friends without going abroad, students practice their writing and reading skills, just like having normal pen pals friends,

\section{METHODOLOGY}

\section{Participants}

Fifty-two students of the second-year of the third semester in the year of 2015/2016 of the Accountancy Department-State Polytechnic of Malang were the participants of this study. Mostly the students' ages were around 20-22 years old. They learned English as a supporting subject for their major subject, namely, Accounting. The students got five semesters for learning English with three hours in a week.

\section{Method of the Study}

The writer used the action research procedure adapted from Elliot, 1991. This study was initiated with the general idea of how the students' positive attitude toward learning Business English can be enhanced by making the most use of the potential of technology? First, reconnaissance, which constitutes analysis of facts and findings, was done. After that, general action plan was designed before it was then implemented. To ensure that the implementation was on the track, it was monitored at the same time. At the end, another reconnaissance was done to identify all problems encountered during the implementation and also the effects of the action.

\section{Preliminary Study}

To identify the students' problems, a preliminary study was conducted by doing observation and interview while the process of 
learning in the classroom was going on. Another preliminary study was also done to identify the problems encountered by the students. From the data that had been taken it was found out that the students' attitude and the students' English ability were still poor. These difficulties were due to some factors

\section{Identifying and clarifying the general idea}

This study was inspired by the fact that there was a discrepancy between the goal and the product of the English learning at the Accountancy Department-State Polytechnic of Malang. Graduates of this Department should possess adequate English proficiency and be ready to use their language ability in real working condition. However, the fact showed that despite the many hours of the learning of English during their study, students of this department have language ability, which was below the target (the average of TOEFL test result was below 450). Most of these students did not have good English ability. Thus, this study was initiated with an idea that the students of the Accountancy Department-State Polytechnic of Malang needed to be improved.

\section{Fact finding and analysis}

During the reconnaissance (fact finding and analysis) phase, the real situation including students' problem in learning English were described. In this phase, students were introduced to the project proposed - Problem Based Learning. The project assigned students to work in groups that performed as Pseudo Companies. There were two classes with four groups representing four different companies in each class.

The firsts project was entitled "Setting Up Business 1" in this assignment they were asked to create the soft data (the material was searched from the internet and students'major subjects learnt in their classroom) and then perform; a. Budget estimation for a year, b. Product in details and specifications c. Chanel and area distributions in the form of a business meeting as the fi ished product, and were identified and analyzed as well

\section{Constructing the general plan}

The steps in the action research for constructing the general plan were as follows: first, designing the steps of the business project that were assigned to improve their English abil- ity and attitude toward English learning; second, preparing the course outline and the schedule of the implementation of the project to get the data; third, creating the criteria of success to measure the level of students' comprehension; and fourth, preparing the instruments, a media to get the data. As the present study tried to enhance the students English ability and the students 'attitude so the source of the materials were prepared by the students by finding the authentic articles from the Internet and the students' major subject learnt.

\section{Implementing the action}

The implementation of the action research was the activities done as arranged in the lesson plan. The teacher-researcher implemented the schedule of the implementation as designed.

\section{Monitoring the implementation and effects}

During this phase, the teacher-researcher monitored the implementation of the actions as previously planned as well as monitored both intended and unintended effects of the actions. In this phase, data gathering was conducted. The data gathered dealt with the students' activities and improvements. Then, the data were described and reflected to the general idea, whether the students' English skills and attitude were improved.

\section{Reconnaissance}

In this phase, all facts including the success and the failure of the implementation of the plan as well as the effects of the actions were described. The effects covered the intended and unintended ones. In the project, the students were supposed to work in group representing one pseudo company. Each class from the two classes of the students under study was grouped into four groups forming four different companies. They had to work with two topics on business meeting as described in Table 1.

The first and the second project were done in 12 meetings, with each project being used for six meetings. The firs meeting was used to introduce the project and informed about what the students had to do. The second up to the fourth meetings were used to give the consultation while the fifth and the sixth meetings were used for the students' presentation.

Table 1. Students project

\begin{tabular}{lll}
\hline NO & Project assigned & Time allocated \\
\hline 1 & "SETTING UP BUSINESS 1" & 5 meetings - \\
creating the soft data and presentation on; & 90 minutes for each meeting \\
a. Budget estimation for a year & (3 meetings for doing preparation and consultation, \\
& b. Product in details and specifications & 2 meetings for doing the presentations (4 groups) \\
& c. Chanel and area distributions & \\
& "SETTING UP BUSINESS 2" & 5 meetings - \\
& creating the soft data and presentation on; & 90 minutes for each meeting \\
& a. The design, the quality and the process of the product & (3 meetings for doing preparation and consultation, \\
b. The price decision & 2 meetings for doing the presentations (4 groups) \\
& c. The brand legalization & \\
d. The electric advertisement and brochure & \\
\hline
\end{tabular}


Table 2. The instruments used to monitor the implementation

\begin{tabular}{lll}
\hline NO & Instrument & Function \\
\hline 1 & Pretest & $\begin{array}{l}\text { First, pretest was used to measure their English skill and their attitude towards the } \\
\text { implementation of the program. } \\
\text { Second, project planning form was used by the students to write the planned activities in } \\
\text { order to complete each project assigned to them. }\end{array}$ \\
3 & Project planning form, & $\begin{array}{l}\text { Third, weekly report was used by the teacher to monitor the students' activities by recording } \\
\text { their daily and weekly activities. }\end{array}$ \\
4 & Observation check list & $\begin{array}{l}\text { Fourth, observation check list was provided to monitor the students' progress. } \\
\text { Last, questionnaire was also prepared to explore feedback on the project implementation } \\
\text { from the students. }\end{array}$ \\
\hline
\end{tabular}

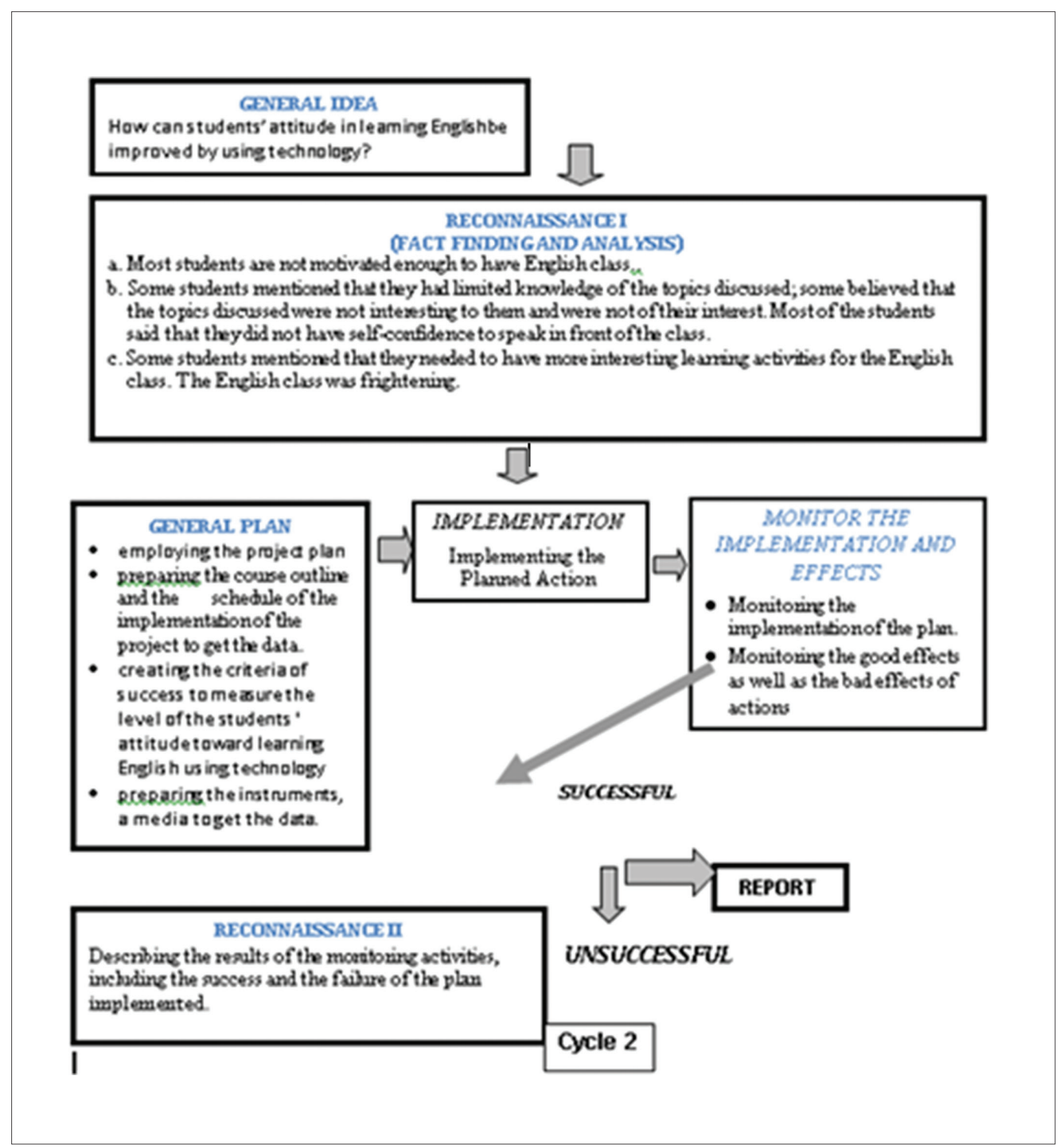

Figure 1. Cycle 1 (Adopted from Stroller, 1997)

Students created the content/sources of the data of the presentation from the internet and their major subjects that were learning. Even though selecting materials was little bit time consuming but it seemed students were happy in doing it. 


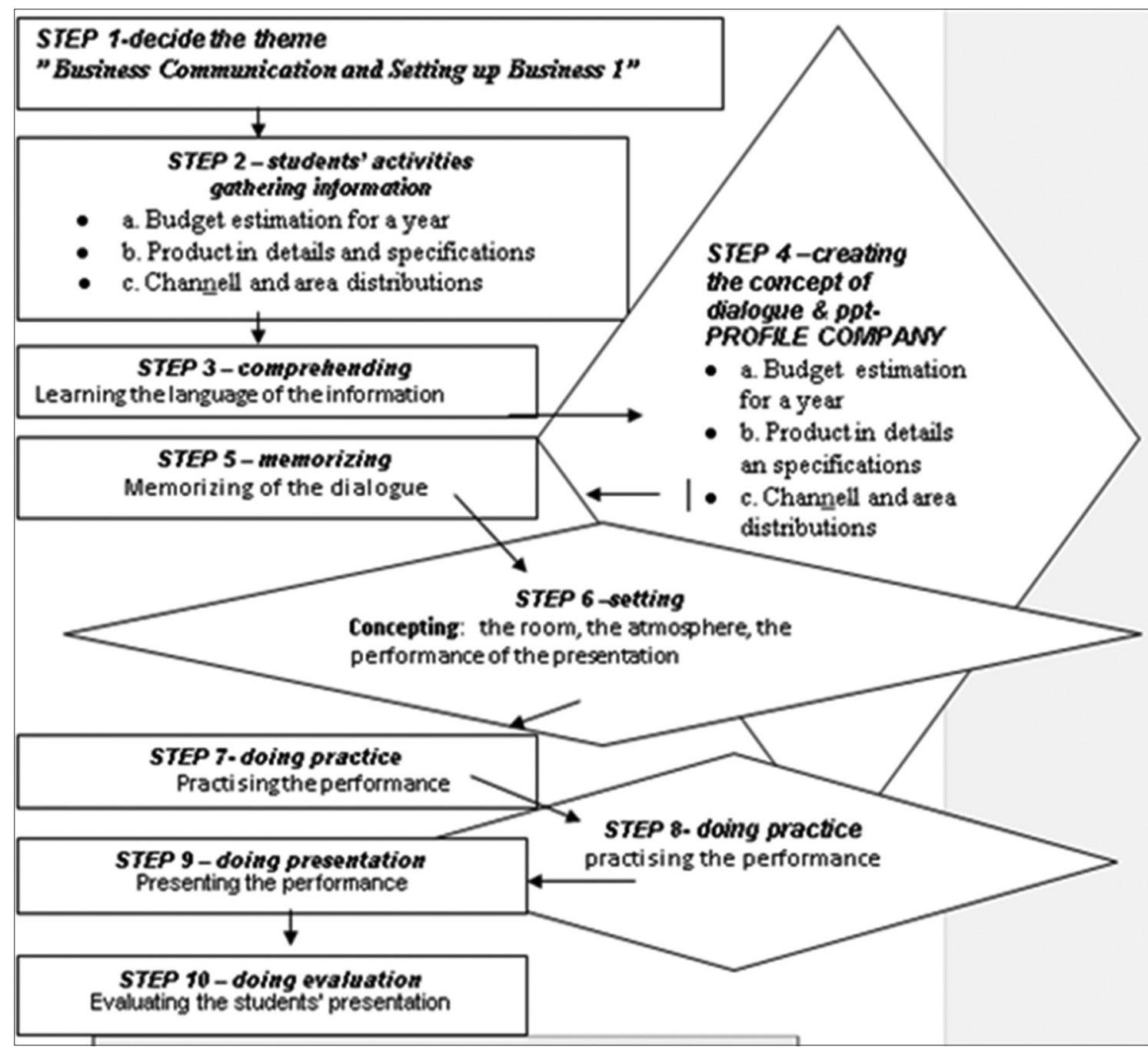

Figure 2. Flowchart for Students' Activities

\section{Instruments}

As seen in Table 2, several instruments were prepared in order to ensure that the implementation of the project-based instruction was successfully monitored:

\section{FINDING}

The students' attitude was observed from the students' process of doing the project in the classroom, continued by doing consultations with the teacher-researcher, and ended by doing the presentation (the presentation' conducted was a business meeting in a natural atmosphere performed as Pseudo Company).

To be precise, the first observation was on giving the pretest to see the students' comprehension on a certain text and their ability in speaking. The teacher-researcher prepared some texts to be used as a media to measure the students' ability. The pre-test was in the form of an oral test. Every student should meet the teacher researcher in 10 minutes to retell the story of the text prepared that had been comprehended before and to answer the teacher researcher' questions about the retold story to see the students' comprehension. The two skills were tested at the same time: skill in comprehending the text and skill in speaking ability.
A media used to observe the student's attitude in integrating technology to learn Business English was doing the two projects, the teacher-researcher pushed a lot on the students' motivation and it was success. One of the successes was measured from the atmosphere faced by the teacher-researcher, the atmosphere was warmer, and tolerance was increased because some students were good in operating the computer but some were not. In the consultation, the students asked to have the consultation not only when they were learning in the classroom but also in outside the classroom. Even though their work did not come to the right assignment but they did not feel discouraged. They insisted on the next days to get the correct assignment. Creativities, critical thinking, tolerance, responsibility could also be seen during the journey of learning.

The students' creativities could be observed clearly a) from the content created in the power point, b) from the process of conducting the meeting (dialogue), c) from the whole performance of the presentation d) from the atmosphere created - natural atmosphere of a business meeting, e) from setting the room to be created - f) including the uniform worn by the students. Creativities were also learnt from the teacher-researcher and browsed from the internet that opened the 
Table 3. The questionnaire responded by the students

\begin{tabular}{|c|c|c|c|c|c|}
\hline No. & Questions & Agree & Neutral & Disagree & Total \\
\hline 1. & $\begin{array}{l}\text { Using of Technology in our language classroom increases my creativities and } \\
\text { my responsible }\end{array}$ & 52 & - & - & 52 \\
\hline 2. & $\begin{array}{l}\text { Using of Technology in our language classroom increases my motivation in } \\
\text { learning English. }\end{array}$ & 52 & - & - & 52 \\
\hline 3. & We should use technology in our classroom for every lesson & 10 & 20 & 22 & 52 \\
\hline 4. & $\begin{array}{l}\text { Authentic materials downloaded from the internet make us active in the } \\
\text { learning process }\end{array}$ & 38 & - & 14 & 52 \\
\hline 5. & Computer-based teaching activities make the lessons more enjoyable. & 42 & 10 & - & $52-$ \\
\hline 6. & Technology is not useful and unnecessary to be implemented. & - & - & 52 & 52 \\
\hline 7. & Presenting our assignment using power point create our Creativities & 52 & & - & 52 \\
\hline 8. & $\begin{array}{l}\text { Presenting our assignment using power point help us to understand the } \\
\text { materials better. }\end{array}$ & 52 & & - & 52 \\
\hline 9. & Films, videos, CDs and e-learning can be helpful to develop my language skills & 45 & 7 & - & 52 \\
\hline 10. & Films, videos, CDs and e-learning can be helpful to develop my language skills. & 52 & & - & 52 \\
\hline 11. & When we use technology every time, it makes the lesson boring & - & 15 & 37 & 52 \\
\hline 12. & My teacher should use more technology in the classroom & - & - & 52 & 52 \\
\hline 13. & $\begin{array}{l}\text { Computer-based lessons are more enjoyable and effective than traditional } \\
\text { lessons. }\end{array}$ & 45 & 7 & - & 52 \\
\hline
\end{tabular}

Table 4. Students' dialogue in the presentation

\begin{tabular}{ll}
\hline IM & This morning we are going to discuss the problem we face \\
LN & Yes sir, may I propose some solutions related to it, how if we sell the previous product cheaper than the price we \\
have, we promote a discount up to $30 \%$, and also reconsider our area distribution \\
WA & I would say we do clearance on our raw materials \\
UL & that's a good idea..! we have to reconsider our management system also \\
LN & We spend all the old stock of our raw materials \\
IM & All right. I think, we can do some ways \\
IQ & and now... our serious problem is on the marketing job, I think we have to improve our design of our advertisement, \\
LN & and also to wider our area distribution to the east area what do you think... \\
IM & Absolutely right. \\
So, we close the meeting, good luck.. Having good working..and we meet again on next week...at the same time and place
\end{tabular}

views of the students' mind. Creativity is needed for survival either in the working field later or outside of it

The characteristics of enhancing students' English ability and attitude allowed students to empower their own learning. The model gave an opportunity to develop skills such as working in a team, sharping students' creativities, raising students' tolerance, increasing students' responsibility and motivating students to learn English, those skills were quite appropriate with the Polytechnic-students working field later on.

All of the students agreed that the Use of Technology in the students' language classroom increased students' creativities and students' responsibility in learning English. No one chose either neutral or disagrees. With some kinds of technological apparatus, the students feel the atmosphere of more freedom and motivation. They become more active, more exited, and more involved in the process of language learning. 52 students agreed that using of Technology in the language classroom increase students' motivation in learning English. Below is a part of the dialogue related to the - questionnaire no.1 We could see the students' motivation in creating a dialogue, their feeling were really involved on the assignment, the students' responsible were quite wonderful.

In fact it was stated that not all the students agreed to use technology for every lesson they had; students needed variations, such as discussing a topic, playing games and even some times students needed a variety of strategy to be implemented. But 38 students agreed that authentic materials downloaded from the internet made the students active in the learning process although 14 students thought that authentic materials sometimes were not easy to be comprehended, but it would depend on the type of the materials browsed. 42 students thought that Computer-based teaching activities made the lessons more enjoyable and 10 students chose neutral, since they did not have an idea whether 


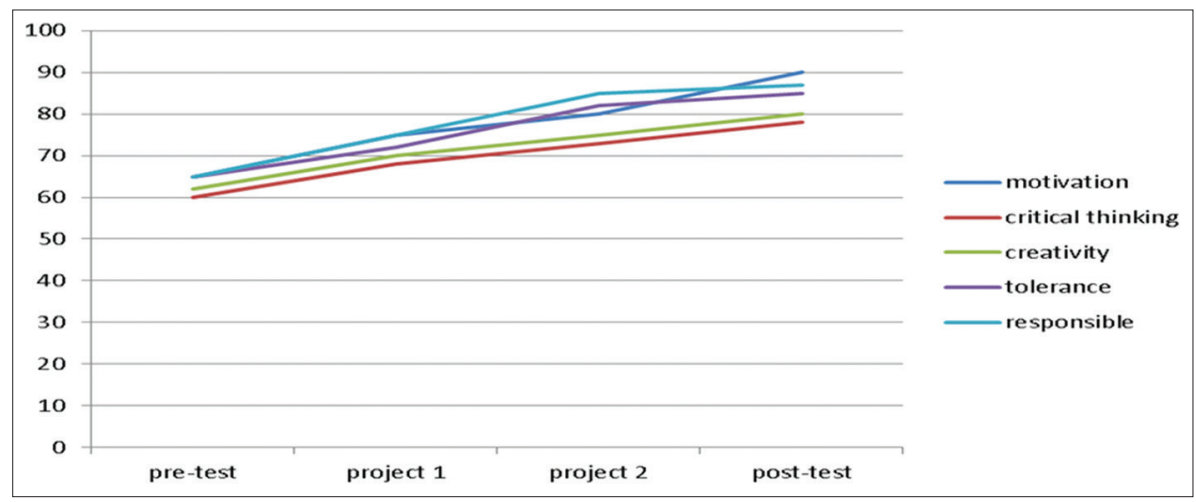

Figure 3. The Improvement of Students' Scores

agreed or disagreed and fortunately no one disagreed to the question.

All the students were disagreeing that Technology was not useful and unnecessary to be implemented. And all the students agreed that presenting assignment-using power point created students 'creativities. All the students considered that presenting assignment using power point helped them to understand the materials better. While 45 students agreed and 7 students chose neutral toward to watch films, videos, CDs and e-learning that could be helpful to develop language skills. All the students agreed that we should use technology during working the project assigned by the teachers in EFL classes since it would make the job easier, effective and efficient. 15 students chose neutral and 37 disagreed about using technology every time made the lessons boring, actually it would depend on how teachers implemented the materials and developed it.

To avoid boring and to get more varieties teachers should use more technology in the classroom. However, 45 students agreed and 7 students chose neutral for using Computer-based lessons were more enjoyable and effective than traditional lessons, since it has sound, music, and colors that would make the learning more enjoyable and lively.

\section{CONCLUSION}

Teaching with technology will reinforce the teacher's role. It has new challenges and proposes enthusiasm and willingness. In Computer Assisted Language Learning, the teacher serves as a facilitator and consultant. A teacher has to provide the students with technical support, train them, and respond to individual students' needs, comments, and requests. Most of the students agreed that learning English assisted with technology (computer and internet) made the students' motivation were increased, the students' creativities were sharped, the students' responsibility were better improved, the students' tolerance was practiced, the students' confidence was also raised

\section{REFERENCES}

Anderson, R, \& B. Speck. (2001). Using technology in K-8 literacy classrooms. Upper Saddle River, N: J: Prentice Hall.

Brown, D. (2003). Developing faculty to use technology. Balton, Anker Publishing company.

Blake, Robert. J. (2008). Brave New Digital Classroom. Washington, D. C. Georgetown University Press. Chartrand, R.G. (2002) “The Effectiveness of Using Computer Assisted Instruction in Teaching English as a Foreign Language in a Japanese Secondary School (Fukuoka, Japan)". MA TESOL Collection. Paper 389.

Chin, P. (2004). Using C \& IT to support teaching. London: RoutledgeFalmer.

Elliot, John, Dipl.Phil.Ed (1991). Action Research for Educational Change. Open University Press, Celtic Court 22 Ballmoor, Buckingham MK18 1XW.

Gordon, T. (2007).Teaching young children a second language. California: Greenwood Publishing Group Hamad Yousef Al-Maini. Using Technology in EFL in Saudi Arabia. Maini. Literacy Information and Computer Education Journal (LICEJ), Volume 2, Issue 3, September 2011

Jonassen, D. H. (2000). Computers as mind tools for schools: Engaging critical thinking. Upper Saddle River, NJ: Prentice Hall.

O'eeary, R. (2005). Online communication using discussion boards. The Handbook for Economics Lecturers. Retrieved February 2012, from http://www.economicsnetwork.ac.uk.

Roberts, T. S. (2005).Computer-supported collaborative learning in higher education. In T. S. Roberts (Ed.), Computer-supported collaborative learning in higher education (pp. 1-18). Hershey, PA: Idea Group Pub.

Schulte, A. (2010). The development of an asynchronous computer-mediated course: Observations on how to promote interactivity. College Teaching, 52 (1), 6-10.

Stroller, F. L. Vol 35 No 4, October - December 1997 Page 2 - Project Work: dosfan.lib.uic.edu/usia/E-USIA/forum/vols/vol35/no4/p2.htm

Wang, Y. (2004). English magazines, Motivation+ improved EFL writing skill. English Teaching Forum. January. 